The impact of Exchange rate on Macroeconomic fundamentals دـ \سعد محمد اسماعيل الغايش

The impact of Exchange rate on Macroeconomic fundamentals In Egypt

$$
\begin{aligned}
& \text { دـ \مسعد محمد اسماعيل الغايش } \\
& \text { استاذ الاقتصاد المساعد } \\
& \text { كلية السياسة و الاقتصاد } \\
& \text { جامعة بني سويف }
\end{aligned}
$$

mosaad2000@eps.bsu.edu.eg

Mobile $\quad 01288337884$ 


\title{
The impact of Exchange rate on Macroeconomic fundamentals
}

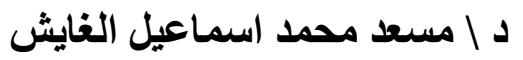

\section{The impact of Exchange rate on Macroeconomic fundamentals \\ In Egypt}

\begin{abstract}
The Arab Republic of Egypt followed various exchange rate policies over the past three decades. In November 2016, Egypt followed the policy of floating exchange rates in line with the recommendations of the International Monetary Fund (IMF). The problem of research is about how the various exchange rate policies in Egypt affected some macroeconomic variables such as economic growth, Unemployment rate, inflation rate, trade balance deficit, external debt and international reserves. The study concluded that there is a clear difference in the impact of the exchange rate on the economic variables under study. The results of the decision to liberalize the exchange rate confirm the validity of the delayed decision to float the exchange rate. The study recommended a set of recommendations, the most important of which is the need to maintain the policy of exchange rate liberalization, the promotion of Egyptian exports and the entry into international competition, especially after the floating decision which helps to increase The competitiveness of Egyptian exports, and finally the need to rely on a basket of currencies rather than relying mainly on the dollar.
\end{abstract}

Key words

Policies - Exchange Rate - Egypt - Growth Rate - Unemployment Rate - Inflation Rate - International Reserves - Trade balance deficit - Foreign Debt

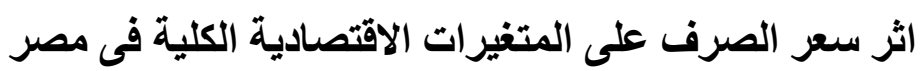

المستخلص

اتبعت جمهورية مصر العربية سياسات متنوعة لسعر الصرف علي مدار العقود الثلاث الماضية ، وفي

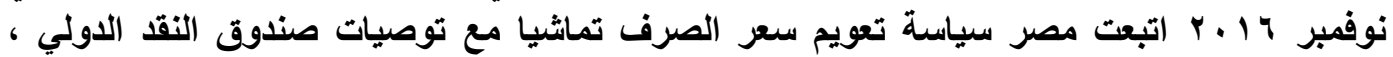

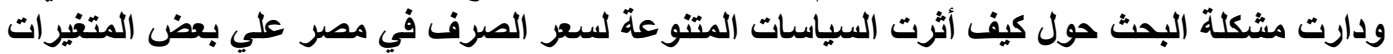

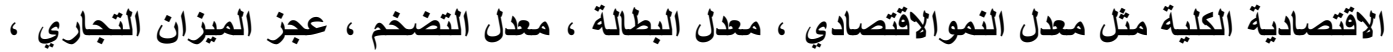

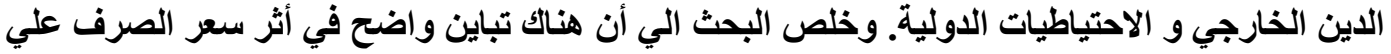

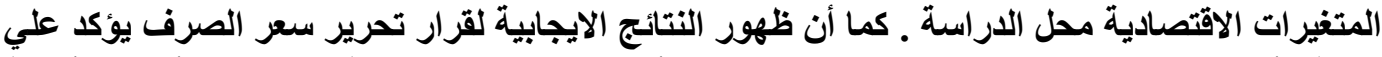
صحة تأخر اتخاذ قرار التعويم لسعر الصرف ، وقد أوصي التهي البحث بمجموعة التوصيات أهمها، أهمية

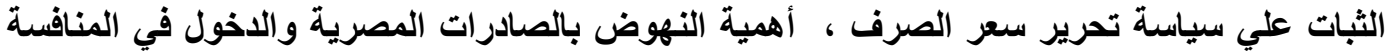
الاولية خاصة بعد قرار التعويم و الذي يساعد علي زيادة القدرة التنافسية للصادرات المصرية ،واتية ،واخيرا

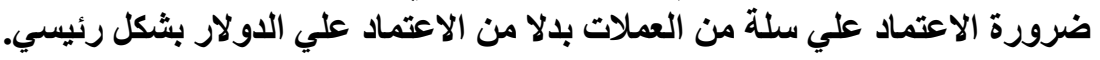
الكلمات المفتاحية

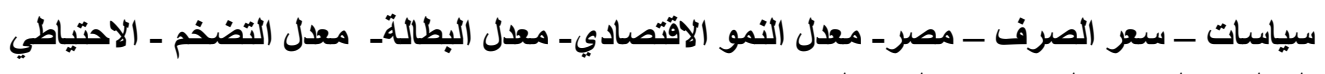
الدولي - الميزان التجاري الدين الخارجي 


\section{The impact of Exchange rate on Macroeconomic fundamentals}

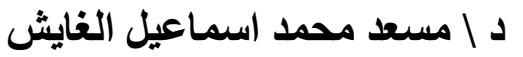

\section{Introduction}

Exchange rate is an important and effective instrument of monetary policy, and this tool plays an important role in solving the problems of the national economy of any country provided they are used correctly (central bank of Egypt 2014). The decision of the type of exchange rate policy by responsible for the management of monetary policy depends largely on the state of the economy at the time, each type of exchange rate policies at the time that corresponds to the state of the economy. For example, the policy of fixing the exchange rate requires sufficient reserves of foreign currency at the central bank to be able to maintain the exchange rate at the required level. The economic reform program adopted by Egypt following the June Revolution required several crucial decisions to build an attractive infrastructure for foreign direct investment, solve the energy problem, formulate an effective fiscal policy, rationalize public spending, and raise tax revenues and other critical decisions adopted by the Egyptian political leadership, Among these important decisions recommended by the International Monetary Fund was the decision to float the exchange rate. In November 2016, the Central Bank of Egypt (CBE) adopted a bold decision to float and liberalize the exchange rate in accordance with the recommendations of the International Monetary Fund (IMF) as part of its economic reform program.

\section{r. Research problem and limits}

Egypt followed a variety of exchange rate policies. The fixed exchange rate policy followed by the floating exchange rate policy in 2003 and the latter in 2016 followed the floating exchange rate policy. The problem of research was summarized in the following question: How varied exchange rate policies in Egypt in the last three decades on some macroeconomic variables such as economic growth rate, unemployment rate, inflation rate, trade balance deficit, external debt, international reserves. The study is limited to studying the impact of the various exchange rate policies adapted by Egypt from 1990 to 2018.

\section{r. Objective, hypothesis, and importance of research}

The research aims to measure the impact of the exchange rate on some of the important macroeconomic variables mentioned above. While the main hypothesis says that the effects of Egypt's adoption of a 


\section{The impact of Exchange rate on Macroeconomic fundamentals}

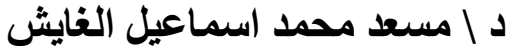

variety of exchange rate policies varied, and Egypt was too late in pursuing the floating exchange rate policy. therefore the importance of the research in the statement of the impact on those variables, especially as it was followed by a significant rise in prices and a reluctance to underestimate the balance of trade and other effects on the rest of the variables, which explains the importance of the researcher in this study.

\section{Research Methodology}

The multiple linear regression models was used in the least squares method using the stepwise regression method, depending on the SPSS program. This was done based on time series during the period (19902018) by using World Bank data for all variables on the EVIEWS statistical program and conducting the Augmented Dickey-Fuller Test Equation and Phillips-Perron test statistic tests. All the variables were static at the level. All the results of the previous models were presented using PATH ANALYSIS networks to illustrate the direct and indirect effect of the growth exchange rate $\left(\mathbf{G}_{-} \mathbf{E X}\right)$ on all previous variables. All previous regression models were estimated. All of them found the problem of self-correlation of the condom using the DurbinWatson stat test. The problem of heterogeneity was tested, and the Heteroskedasticity test was used. The result was that all models did not contain this problem Using the $A R C H$ method, as well as the normal distribution of the gears. The models' estimates were based on the measurement problems.

\section{5 .Previous studies}

Several studies examined the relationship between the exchange rate and some macroeconomic variables. In the late 1980s, (Krugman 1979) studied the currency markets in Latin America, which concluded that there was a relationship between the external deficit, monetary and monetary expansion policies. (Agenor study 1992) also presented a study showing the direct impact of the exchange rate on the balance of payments crises and the impact on international reserves. The study also showed that the expansion of the black market due to the fixed exchange rate weakens the effectiveness of capital control, which increases the problem of capital flight and increase the degree of substitution between the local currency and foreign currency. Another study (Mepherson 2000) found an indirect 


\section{The impact of Exchange rate on Macroeconomic fundamentals}

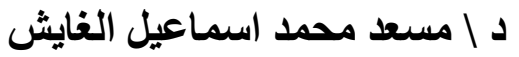

relationship between the exchange rate and the economic growth rate in Kenya by means of several variables including investment, foreign aid and imports, and in turn these variables affected the growth rate of the GDP. And the study of (Boyared and caporale 2001) proved that there was also a positive relationship between the low exchange rate of the local currency and the improvement in the balance of trade in a study conducted on eight developed countries. In another study (Rutasitara 2004 study) found that the exchange rate had a clear effect on the high rate of inflation in Tanzania. The fixed exchange rate discouraged and constrained inflation and the overall average price in Tanzania did not increase, which helped attract foreign investment. In 2007, there was a study by (Kandil and others2007). The study found an inverse relationship between the exchange rate on both the demand for investment and exports as well as the inverse relation to economic growth rate. As (Ashour 2009) found in a study conducted by a group of developing countries found a relationship between the rate of growth and the adoption of the fixed exchange rate higher than if followed by flexible exchange rates. In an Indian study by (Ratha 2010), the study showed a difference between the effect of the exchange rate on the rate of growth of output, while in the short term there is an inverse relationship between the two variables, but in the long run the effect becomes positive. Beside a study on the Ethiopian economy presented by (Ayen 2014) concluded that there was an inverse relationship between devaluation of the local currency and the rate of economic growth in the long term and neutral in the short term.

The study also showed that the Ethiopian government should not liberalize the exchange rate. In a recent study (Christian Payne 2016) showed that there was an inverse relationship between exchange rate fluctuations and economic growth rate in Ghana in both the short and long terms. The study recommended that the fixed exchange rate in Ghana should be followed to avoid the negative impact of exchange rate fluctuations.

\section{Effect of the exchange rate on the economic variables}

The exchange rate regime in Egypt until 2003 - Ganzouri Ministry was the fixed exchange rate system, where the rate of exchange rate growth stabilized at 3.4 pound per dollar After 2003, the Ministry of Foreign Affairs and Finance - Atef Ebeid-, the floating exchange rate 


\section{The impact of Exchange rate on Macroeconomic fundamentals}

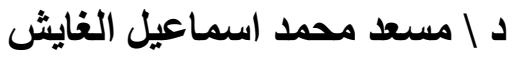

was applied. The exchange rate exceeded the price of the dollar by seven Egyptian pounds and the rate of growth of the exchange rate was 5.9 to 7.1 between 2003 and 2016, and in November 2016 the decision was taken to liberalize the exchange rate completely, as the price of the dollar approached 18 pounds, Where the rate of growth of the exchange rate ranged from 10 . to 17.8 pounds to the dollar (World Bank), as the Egyptian economy suffered a period of effects resulting from the liberalization of the exchange rate and caused a rise in the exchange rates of other currencies for the Egyptian pound and the resulting rise in prices in general and High inflation rate.

\section{Growth Rate (GDP)}

$G D P=G_{E} E X+E 1$

$G D P=6.948236+0.078466 I R-0.393630 U N E-0.021609 G \_E X$

The economic growth rate has many of the determinants that govern its determination upwards and downwards, and may interfere in determining the exchange rate as a tool of monetary policy. Before determining the extent to which the exchange rate can intervene in determining the economic growth rate using the standard model, the research review the development of the economic growth rate in Egypt beginning in the eighties. The GDP growth rate declined from an average of $9.4 \%$ in $1975-1980$ to $4.5 \%$ in the period from 1990 to 2001 and to $3.6 \%$ in the period 2001-2004. This decline was associated with the sharp decline in the rate of domestic investment from $27 \%$ in $1974-1981$ to $19 \% 2002$ and then to $18 \%$ in the period 2003-2006. The economic growth rate in 2005-2006 increased from $4.9 \%$ to $6.9 \%$, the highest rate of growth is attributed to the development of the performance of the various sectors and main economic activities, including oil, gas, tourism, Suez Canal, industry, construction, communications and information technology, and its growing role as a driving force for the growth of the national economy (World Bank). From 2010 to 2014, due to political instability, the investment rate declined from $16 \%$ of GDP in 2012 to about $11 \%$ in the first quarter of 2013, while sustainable development and high economic growth rates required that the investment rate is between $20-25 \%$ of GDP. 


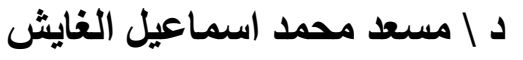

The economic growth rate in $2008 / 2009$ reached $4.7 \%$ and rose to $5.1 \%$ in 2009/2010, but fell to its lowest levels in the last three years, reaching $2.1 \%$ in 2012. (World Bank), then growth rate rose slightly in 2013-2014 to $2.2 \%$. The growth rate increased significantly in the following years $4.3 \%, 4.2 \%$ in 2016 and 2017 respectively, and $15 \%$ in 2018 (World Bank). An inverse correlation between the exchange rate and the economic growth rate was found. From the econometrics model, the exchange rate growth rate of $1 \%$ leads to a decrease in the growth rate of $0.02 \%$ and explains $55 \%$ of the economic growth rate and the remaining $45 \%$. When using the multiple regression models, the inverse correlation between the two variables remained constant, but the coefficient of determination was $61 \%$, which means that the relationship between the two variables increased and the remaining variables, which account for $39 \%$ growth rate, became the only ones.

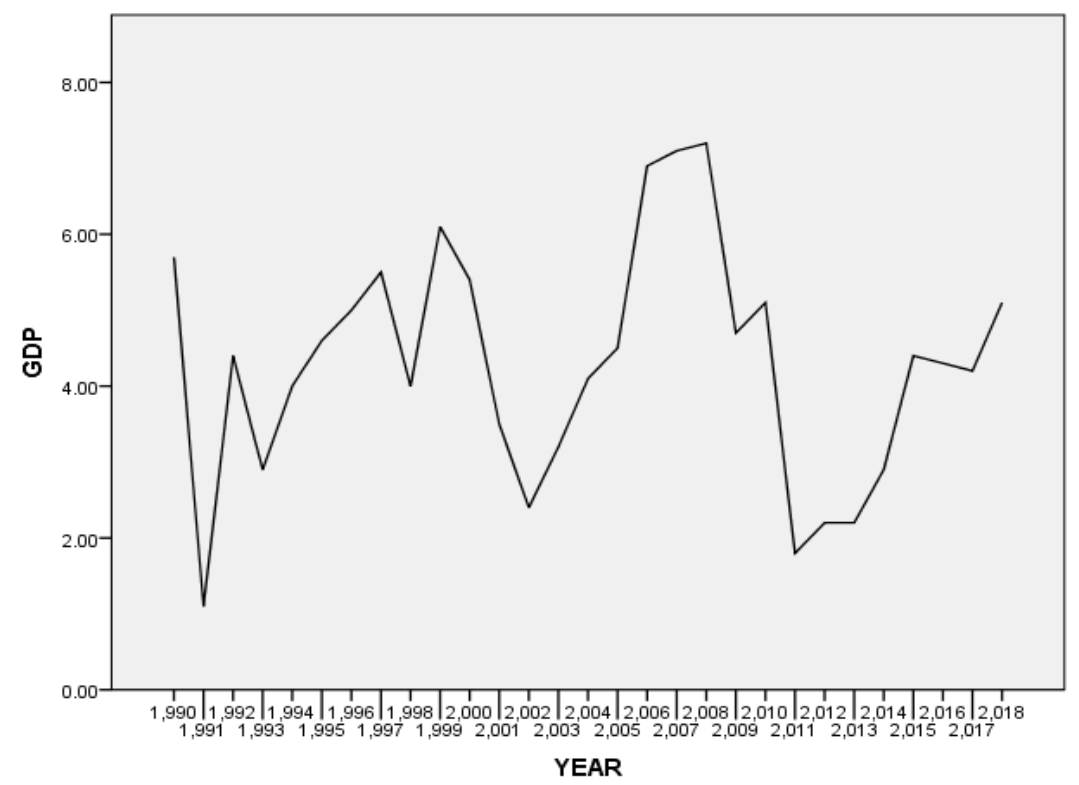

The diagram is designed by the researcher based on World Bank data

\section{Unemployment rate (UNE)}

With a review of unemployment rates in Egypt showed that the unemployment rate in 2000 was $9 \%$ of the labor force, and in 2005 it reached $11.2 \%$. However, the estimate of some international institutions raises this ratio to 20-30 and some sources identified by more than 5.3 million unemployed graduates of universities and higher and intermediate institutes. (World Bank) . Official 
The impact of Exchange rate on Macroeconomic fundamentals

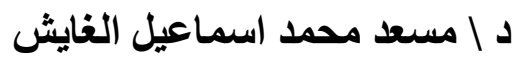

unemployment statistics show that female unemployment is about three times that of men. (Arab Planning Institute). Despite the efforts exerted by Egypt since the revolution of July 1952 to eradicate illiteracy, it ranks ninth in the world in the high illiteracy rate. (Arab Planning Institute)

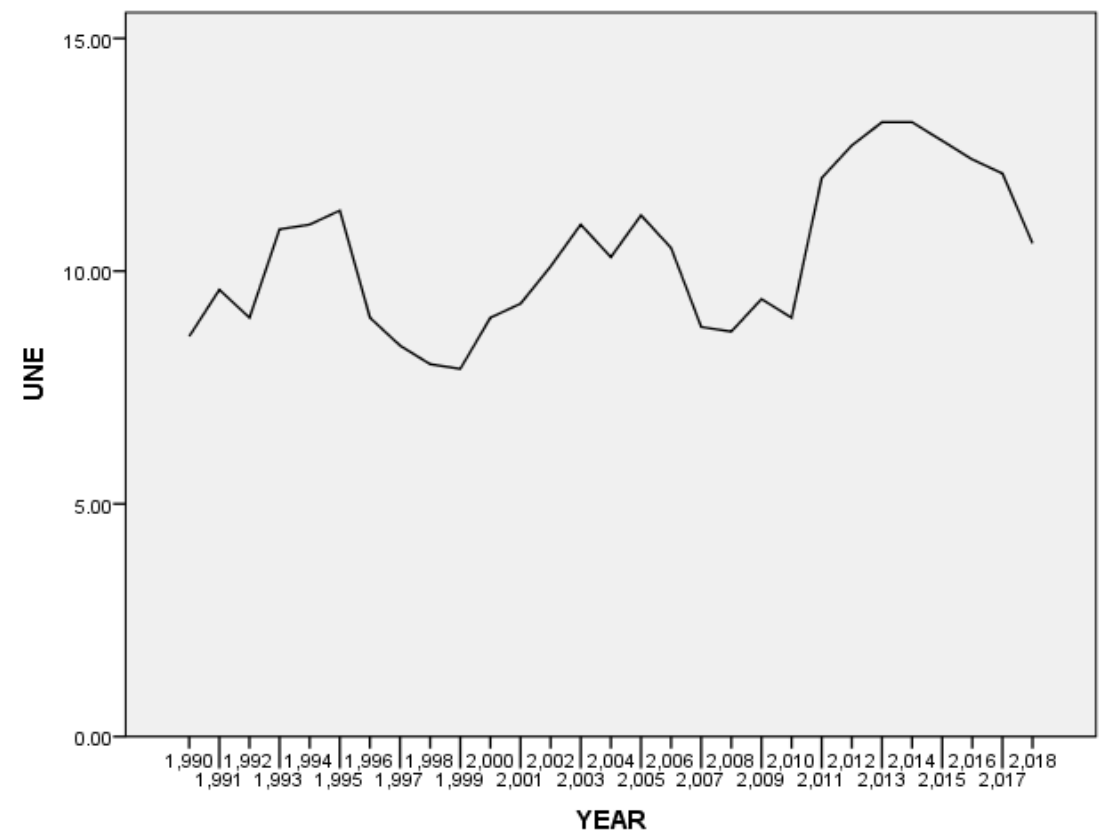

The diagram is designed by the researcher based on World Bank data

In the latest estimates of the unemployment rate, in 2013 it reached $13.4 \%$ of the workforce in the Egyptian market. With the beginning of the period of the new economic reform, which began in 2014, the unemployment rate decreased continuously, reaching $13.2 \%$ in 2014 , then $12.8 \%$ in 2015 , then reaching $12.4 \%$ in 2016 , then $12.1 \%$ in 2017, and finally in 2018, To 10.6\% (World Bank). Since the unemployment rate also depends on many determinants, including the rate of investment, which in turn may be affected by the exchange rate, which is clear from the standard model to the extent of the unemployment rate, is affected by the exchange rate.

Unemployment Rate UNE UNE $=G_{-} E X+E 3$

$U N E=12.79298+0.086932 G_{-} E X D-0.020537 G_{-} E X-0.60131 G D P$ 


\section{The impact of Exchange rate on Macroeconomic fundamentals}

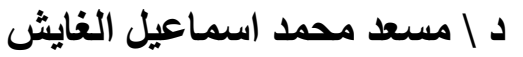

The simple linear regression model showed a positive correlation between the rate of exchange rate growth and the growth rate of unemployment, where the exchange rate growth rate of $1 \%$ leads to an increase in the unemployment rate by $0.01 \%$, while the multiple regression stepwise model showed the reverse relationship, Unemployment is down $0.2 \%$.

\section{Inflation Rate (INF)}

With a review of inflation rates in Egypt found that it ranged from $22.2 \%$ in 1990 to $4.8 \%$ in 1998 , then declined in 2000 to $2.8 \%$, but increased to $13.2 \%$ in 2009 and $12.4 \%$ in 2012. There is no doubt that the high rate of inflation leads to an increase in the balance of payments deficit because it hinders exports and encourages imports and helps to the phenomenon of capital flight abroad. (World Bank). The fact that inflation and its persistence for a long period of time leads to further structural imbalance in the national economy and the imbalance between wages and prices, the deterioration of the purchasing power of money, and affects the individual decisions of investment and savings, Speculation on buildings, land and the tendency to store commodities and refrain from long-term investment (World Bank), The excessive issue of money by the Central Bank of Egypt to the devaluation of the currency and the redistribution of income and wealth, which has hindered the investment process and the flight of capital funds to the difficulty of calculating the real cost. $I N F=G_{-} E X+E 4$

$I N F=1.327963+0.206054 G_{-} E X+0.273844 I R+0.097467 G_{-} T B D$ The correlation between the rate of growth of the exchange rate and the rate of inflation has been shown here. As a result of the increase in the rate of exchange rate growth, inflation increased by $14 \%$. Using the simple regression model, it reached $20 \%$ when the multiple regression models were used. 


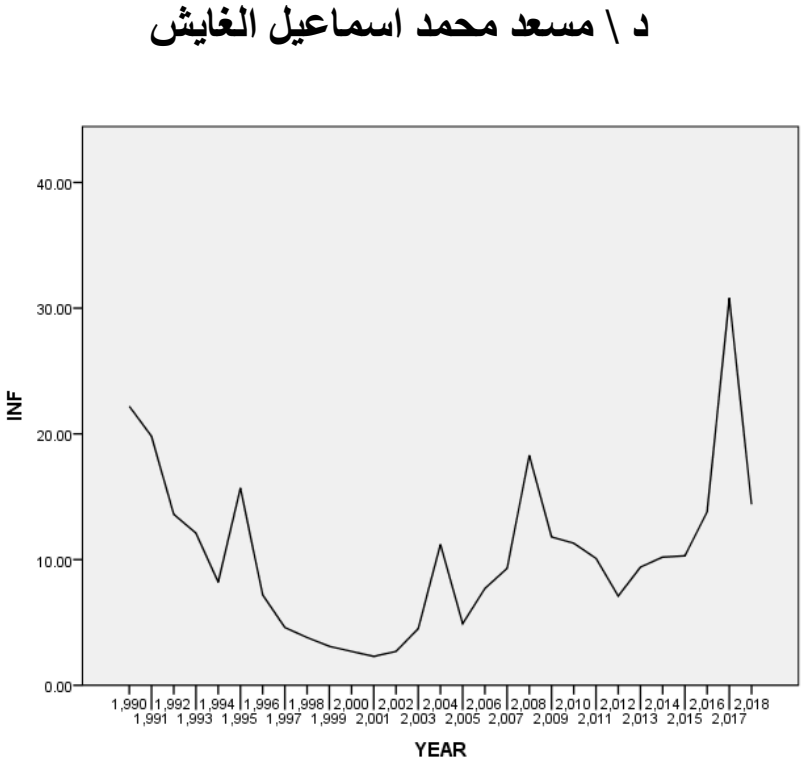

The diagram is designed by the researcher based on World Bank data

\section{Growth External Debt (G_EXD)}

The public debt can be expressed as the sum of the loans received by the State from internal and external loans and their benefits until a certain date. The internal debt includes, in its broad sense, the loans obtained by the government, the public economic bodies and the National Investment Bank, Internal narrow sense. The external debt is limited to the loans obtained by the State from the States and international bodies. It includes soft and soft bilateral loans, loans from international and regional institutions, and net non-resident deposits in the banking system (Mohammad Abdel Halim Omar). By tracking the volume of domestic debt, it found that the record rose from 114 billion pounds in 1993 to 172 billion pounds in 1997, and then reached 330 billion pounds in 2002 and 537 in 2008 and registered to 1650 billion in 2013, and as a proportion of GDP, the ratio of domestic debt to GDP The total in 1994 was about $55 \%$, while in 2005 it was 65\%. In 2009, it reached LE 761 billion, a growth rate far higher than Egypt's GDP growth rate, which in the same year reached only 7.4\% (Manal Afan 2009). While total domestic debt was $61.8 \%$ in 2009 , to $63.8 \%$ in 2010 and then continued to rise to $68 \%$ in 2011 , which means that the safety threshold should not exceed $60 \%$ of the GDP. This rate continued to rise in 2012 and 2013, reaching 71.7\% Then $80.5 \%$, respectively, which indicates a great danger must stand.

In the early nineties of the twentieth century, the volume of external debt of Egypt nearly 55 billion dollars, a large part of which was settled through settlements in the Paris Club to reschedule and reduce 


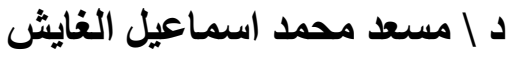

$50 \%$ of net worth, was dropped $50 \%$ of the external debt of Egypt under the Paris Club- The first was the reduction of $15 \%$ of the value on 1991, the second was the total reduction to $35 \%$ of the value on 1993 , and the third where the total reduction to $50 \%$ of the value in 1994 (Ministry of Finance, 2007).

The total external debt of Egypt in 1993 amounted to 30.9 billion dollars, and then fell to 28.8 billion dollars in 1997 and 28.7 in 2002. Although the total external debt decreased from 31.1 billion in 1994 to 29 billion dollars in 2006 The total external debt burden increased from $\$ 1.9$ million in 1994 to $\$ 3.5$ million in 2006 , due to the fact that debt burdens dropped under the Paris Club remained outstanding and payable, but rose to $\$ 33.89$ billion in 2008 and in 2013 To reach more than 45 billion dollars, and then continued to rise in the following years to record 48, 60, 79 billion dollars In the years 2015 and 2016 and 2017 respectively, while exceeding $\$ 90$ billion to record $\$ 92.6$ billion in 2018 (World Bank). These debts may represent a burden on the public budget in favor of banks. Banks have made huge gains despite the difficult economic situation in Egypt while giving up lending to small and medium enterprises. (Central Bank of Egypt 2014)

\section{External debt growth rate (G_EXD)}

$G_{-} E X D=G_{-} E X+E 6$

$G_{-} E X D=-\overline{-} .17397+0.458648 I R+0.197996 G_{-} E X$

Both the simple regression model and the multi-directional regression showed the relationship between the rate of growth of the exchange rate and the external debt of Egypt. The higher the rate of exchange rate growth, the greater the size of the external debt of Egypt is about $19 \%$. This is evident by the doubling of foreign debt since the exchange rate was liberalized in November 2016.

\section{Growth Trade Balance Deficit (G_TBD)}

The balance of payments between the deficit and the surplus at different periods indicates that although the total balance of payments in Egypt achieved a surplus during the period 1994-1997, except for 2003, this surplus became a deficit during the period 1998-2004 - due to the increase in imports at a remarkable rate in 1998, the increase 
The impact of Exchange rate on Macroeconomic fundamentals

دـ \سعد محمد اسماعيل الغايش

rate was $21 \%$ compared to the previous year 1997- while exports decreased by about $19 \%$ in 1998 which led to a significant increase in trade balance (Mostafa Al-Saeed 2003).

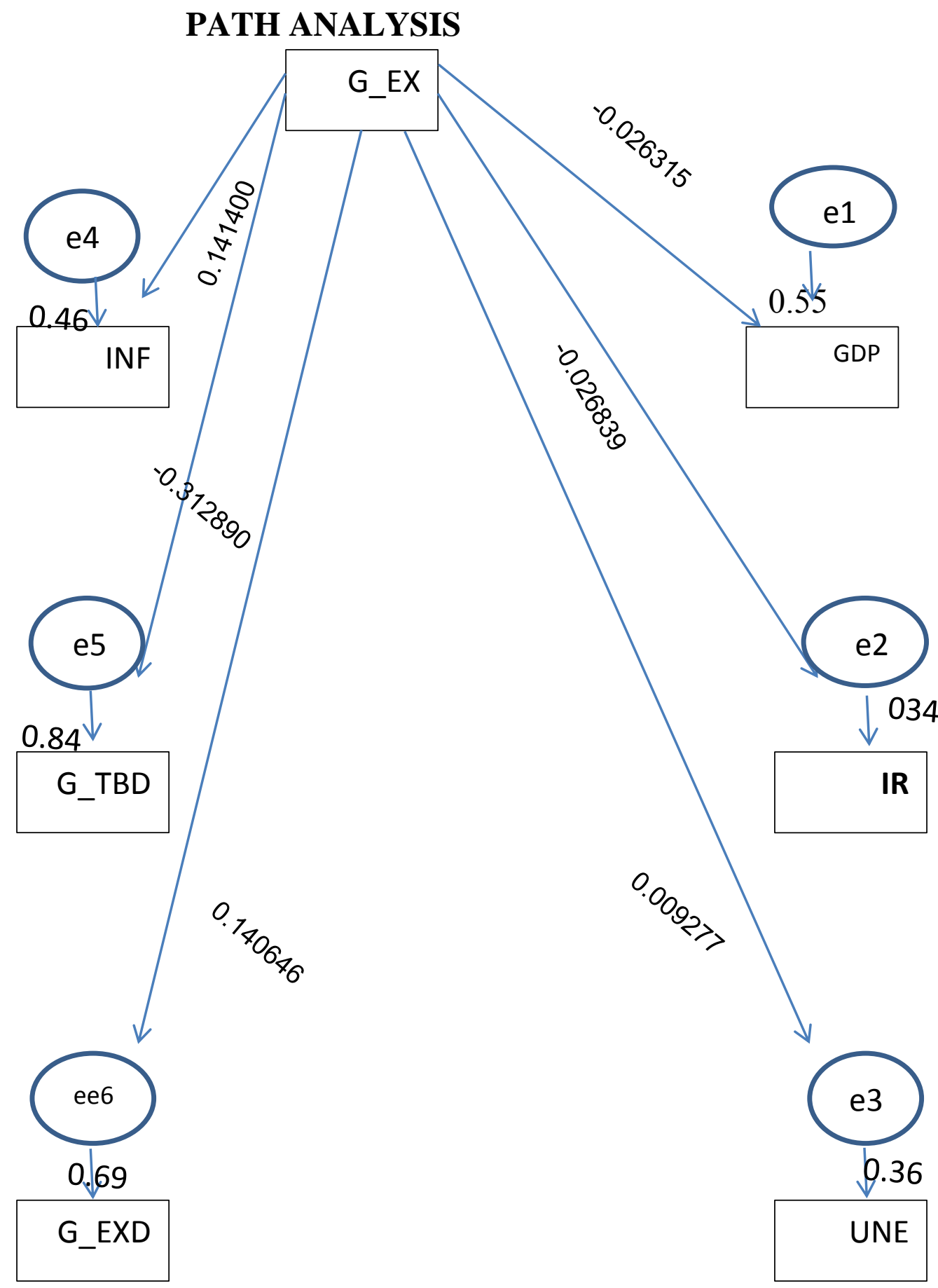

The diagram is designed by the researcher based on World Bank data 


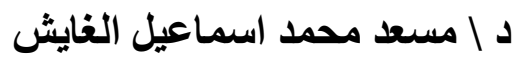

Not only did imports increase sharply in the trade balance there was a decrease in the surplus of the unforeseen balance of services due to the decrease in tourism revenues after the events of Luxor and the return of remittances of Egyptians abroad and a decrease in the surplus of capital transactions, which eventually led to a structural deficit in the balance of payments as a whole, Egyptian Pound (Mostafa Al - Saeed 2003). The external deficit ratio is usually used as an indicator of external balance policy. This indicator is measured using the ratio of deficit or surplus in the trade account to GDP. This is one of the most important indicators of macroeconomic stability and its downward trend indicates the success of policies in achieving the goal of economic stability. Therefore, the trade balance suffers from a structural deficit. The value of commodity imports exceeds the value of commodity exports due to the main dependence on commodity exports, especially petroleum, and some agricultural products and half commodities, which are subject to sharp fluctuations in global demand and therefore fluctuate in prices from one year to another.

This is at a time when commodity imports are concentrated in capital goods or intermediaries that are indispensable for the completion of production operations (National Bank of Egypt 2006).

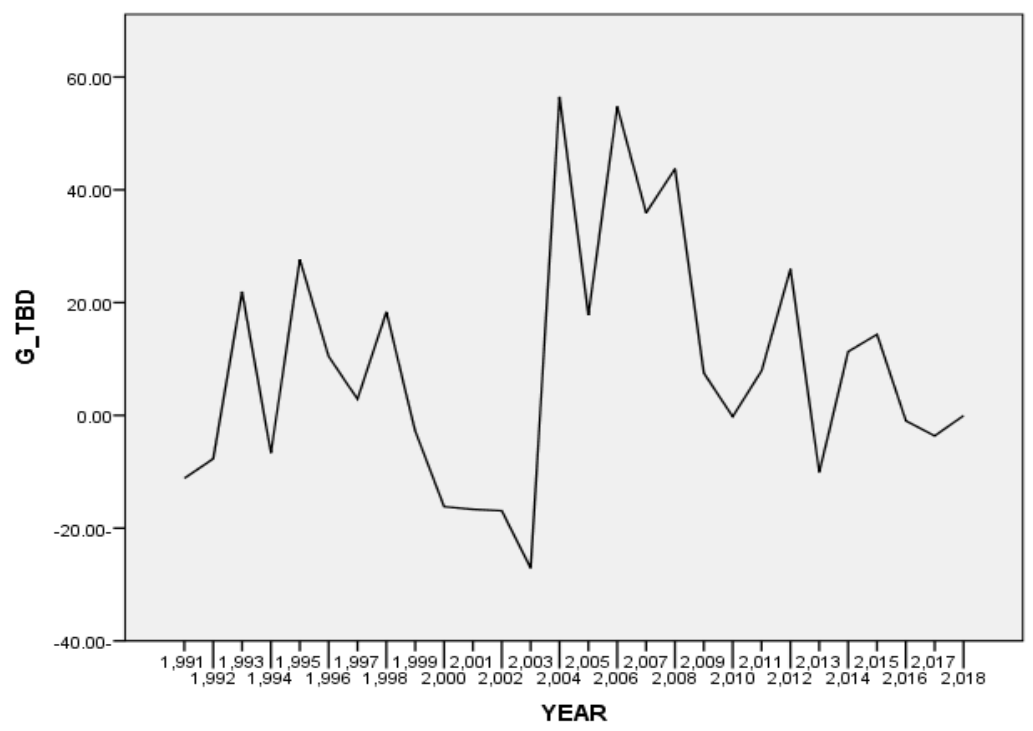

The diagram is designed by the researcher based on World Bank data 


\section{The impact of Exchange rate on Macroeconomic fundamentals}

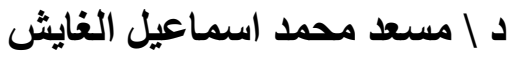

Beginning in 2010, Egypt's trade deficit has witnessed a steady deficit ranging from more than $\$ 25$ billion in 2010 to more than $\$ 27$ billion in 2011 and then to $\$ 34$ billion in 2014, and then the deficit jumped to nearly $\$ 40$ billion in 2015 , Witnessed a significant decline in the period from 2016 to the beginning of the liberalization of the exchange rate in November 2016 to about $\$ 38$ billion and then to about \$ 37 billion in 2018 (World Bank).

$G \_T B D=G \_E X+E 5$

$G \_T B D=-3.920813-0.665186 G \_E X+1.946282 I N F$

The correlation between the exchange rate and the trade deficit was reversed. The simple linear regression model showed that the higher the rate of exchange rate growth, the less the trade balance deficit was $31 \%$. This correlation was also found to be reversible using the multiple regression and reached $66 \%$. This is logical and in line with the fact that Egypt's trade deficit declined from the fiscal year 2017 to 2018. The trade balance deficit fell from about 40 billion dollars to 37 billion dollars in 2018 .

\section{International Reserves (IR)}

Official international reserves are a means of official international payments. The International Monetary Fund (IMF) defines it as the external asset available to the monetary authorities of the State, under its control to meet the needs of balance of payments financing or to intervene in foreign exchange markets to influence the exchange rate. A key condition in the concept of international reserves is that international reserves are at the disposal of monetary authorities. During the period from 1944 to 1968, the US dollar was convertible to gold through the Federal Reserve System, but after 1968 the central banks were able to convert the dollar to gold from the official gold reserves. After the end of the Second World War United States and England toke the decision to established a new international monetary system in Bretton Woods, New Hampshire. The conference adopted a new monetary system based on the dollar exchange rate. The United States committed itself to converting the dollar to gold. As a result, the dollar has become the international reserve currency, thus stabilizing the exchange rates between its various currencies.

The system continued to function until 1971 and after 1973 it was no longer possible to convert any of the other major currencies into gold 
The impact of Exchange rate on Macroeconomic fundamentals

د \سعد محمد اسماعيل الغايش

from the official gold reserves. However, the dollar is still used as official international reserves (IMF 2013). International reserves play a large role in the ability to influence exchange rates because an adequate reserve reserves qualify the central bank to pursue appropriate exchange rate policy, for example, in the case of a fixed exchange rate policy it is necessary that the reserves of major currencies be available Cash to control of the exchange rate.

Structural models using track lines

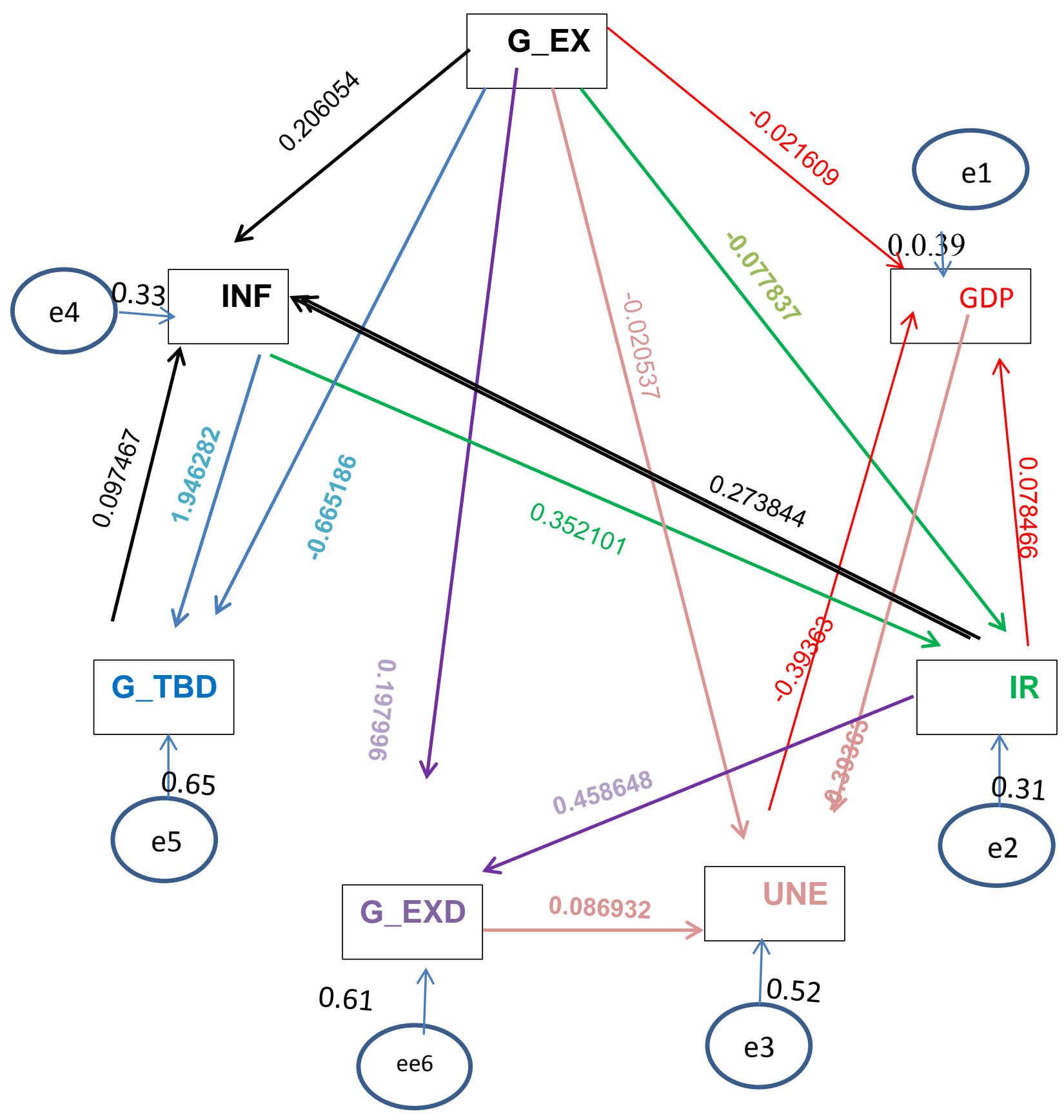




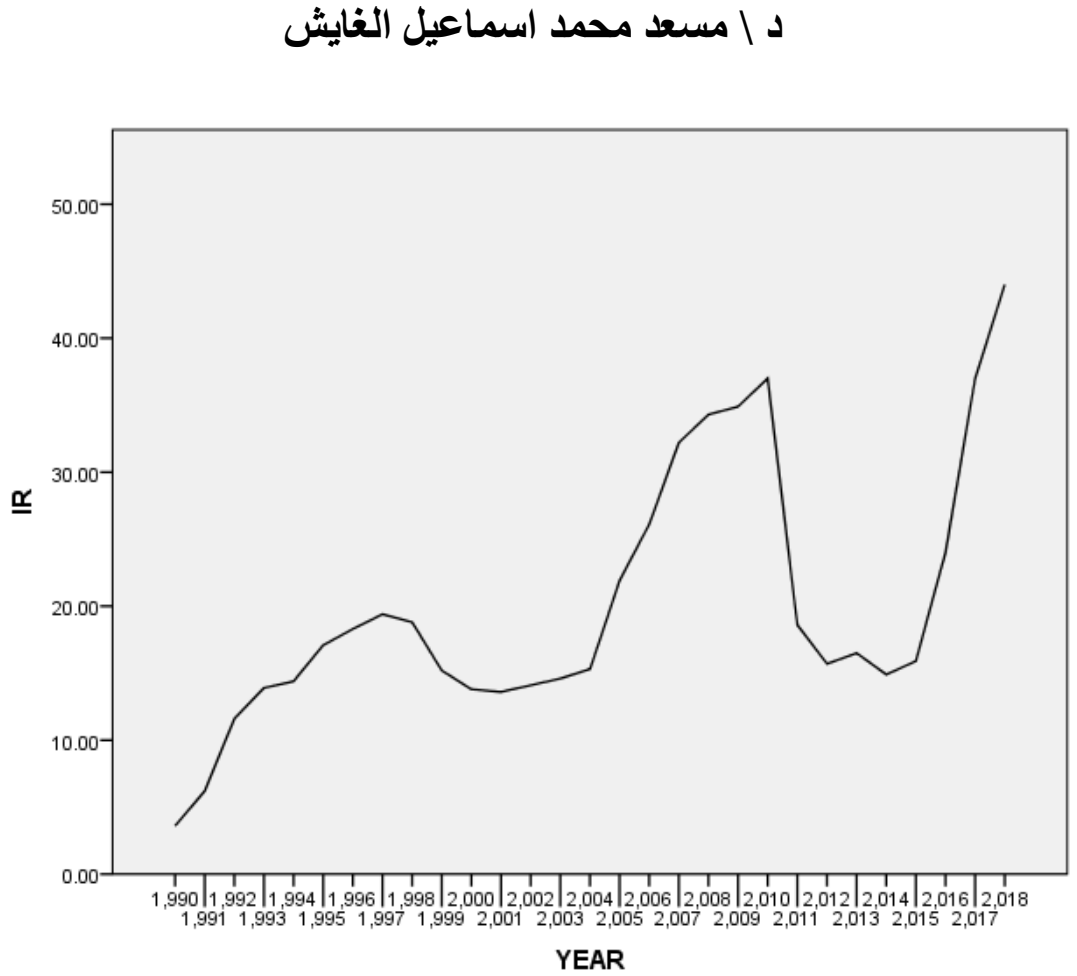

The diagram is designed by the researcher based on World Bank data

If it is necessary to inject a hard currency such as the dollar to the market to fix the exchange rate at a specific price, the central bank can do so, in addition to enhancing the confidence of foreign creditors and investors in the state economy and its ability to meet its external financial obligations. An adequate reserve of international reserves gives the state the ability to withstand external shocks, and it avoids the State borrowing from abroad in the event of unforeseen expenses that require performance against foreign currencies.

The Central Bank of Egypt adopted gold mainly as an international cash reserve in the period before the 1952 revolution, which was the basis of most of the central banks in the world. International reserves stood at $\$ 19.40$ billion in 1997, followed by a continuous decline in reserves of $\$ 18.80$ billion in $1998, \$ 15.19$ billion in 1999 , then $\$$ 13.80 billion in 2000 (10.2 months of imports), $\$ 13.60$ billion in 2001 , and $\$ 14.08$ billion in 2002 Followed by $\$ 14.60$ billion in 2003 (12 months of commodity imports), \$ 15.34 billion in 2004 and \$ 21.86 billion in 2005 (World Bank). After the adoption of the economic reform program - as well as a surge in foreign exchange flows resulting from remittances of Egyptians working abroad following the first Gulf War - and the intervention of monetary policy 


\section{The impact of Exchange rate on Macroeconomic fundamentals}

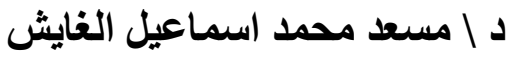

to purchase these flows, reserves of about $\$ 22$ billion (covering about 15 months of imports). The balance of the international reserves of the Central Bank of Egypt witnessed a remarkable development and growth between 2006 and 2010. The balance of international reserves stood at 26.07, 32.21 billion dollars, 34.33 billion, 34.90 billion and 37.03 billion respectively. 2011.

International reserves of foreign currency fell after the January and June revolutions. The net reserves decreased by $\$ 8.6$ billion, or $24.6 \%$, during the fiscal year 2010/2011 to reach $\$ 26.6$ billion at the end of June 2011, compared to $37.0 \%$ Billion dollars at the end of December 2010, and 35.2 billion dollars at the end of June 2010 (the decline amounted to about 9.4 billion dollars, a rate of $26.2 \%$ during the period January / June 2011). One of the reasons for the decline was that tourism revenues declined by $47.5 \%$ during the second half of the fiscal year compared to the first half. Despite the decline in net international reserves, it covered about 6.3 months of commodity imports at the end of June 2011. The decline in net international reserves in 2011 was due to the decline of foreign currencies by about $\$ 9.3$ billion.

Net international reserves in 2012 fell to $\$ 15.5$ billion (3.3 months of commodity imports). Due to the circumstances of the transitional period experienced by Egypt and the consequent exit of investments of foreigners in the form of treasury bills and securities, and also there was a significant decline in tourism revenues.

$$
\begin{aligned}
& I R=G_{E} E X+E 2 \\
& I R=19.48683+0.352101 I N F-0.077837 G E X
\end{aligned}
$$

The standard model showed an inverse relationship between the rate of growth of the exchange rate and international reserves, even at a very low rate, since the exchange rate growth of $1 \%$ leads to a reduction of international reserves of $0.7 \%$. This can be explained by the increase of international reserves about $\$ 44$ billion mostly to the IMF loan as well as grants and deposits from Arab countries such as Saudi Arabia and the UAE to the Central Bank of Egypt. 


\section{The impact of Exchange rate on Macroeconomic fundamentals}

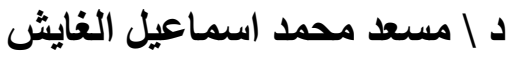

\section{Conclusion}

The standard model emphasized that, there is a clear difference in the effect of the exchange rate on the economic variables studied. For example, there was an inverse relationship between the exchange rate and the rate of economic growth. While exchange rate growth was $1 \%$., the unemployment rate fell by $0.2 \%$. Also the relationship between the exchange rate growth and the rate of inflation was clear, the increase in the exchange rate increased by $14 \%$. Using the simple regression model, $20 \%$ was used when the multiple regression models was used and the reference rate was determined $67 \%$, The correlation between the exchange rate and the external debt of Egypt, where the higher the rate of exchange rate growth, the greater the size of the external debt of Egypt by about 19\%. This was evident by double foreign debt since the exchange rate liberalization in November 2016. But the relationship was reversed between Exchange rate and trade balance deficit. And the emergence of the positive results of the decision to liberalize the exchange rate confirms the validity of the hypothesis of Egypt's delay in taking the decision to float. The deficit in the trade balance has decreased after the implementation of the policy of floating the exchange rate fully compensated, as the trade balance deficit fell to about 37 billion dollars, 2018 after it was 40 billion. This has led to an increase in Egyptian exports and a decrease in the rate of imports as a result of the increase in their prices. The unemployment rate has also fallen to less than $10 \%$ in 2018 , as well as an increase in the economic growth rate due to attracting more foreign direct investments to Egypt, Egypt's loan to the International Monetary Fund. The rate of inflation fell after a peak of 34\% in 2017, falling to $14 \%$ in 2018.

\section{8- Research is therefore recommended}

1- the need to insist on the policy of liberalization of the exchange rate in view of the achievements of attracting more foreign investment as well as Egypt's loan to the International Monetary Fund and the subsequent lifting of the international credit rating of Egypt, as well as the adverse effects of the floating decision began to control the Egyptian economy, for example Inflation has become easy to control. It has fallen to less than 14 after 34\% and the trade balance deficit has fallen. 


\section{The impact of Exchange rate on Macroeconomic fundamentals}

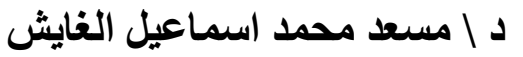

2- The role of the promotion of Egyptian exports to enter the international competition in areas where Egypt enjoys comparative advantages especially after the flotation decision, which helps to increase the competitiveness of Egyptian exports.

3- - the need to rely on a basket of currencies instead of relying on the dollar mainly.For example, the floating of the exchange rate in Egypt has led to a clear rise in prices, because the development of a mechanism to deal with the negative effects of the resolution limits the shocks to the national economy .

\section{References}

1- Agenor, P, 1992, Parallel currency markets in developing countries: theory evidence and policy implication, essays in international finance , No, 188, Princeton university, new jersey,pp2,3

2- Arab Planning Institute in Kuwait, the official website, http://www.arabapi.org/

3- Ashour, Magda Bint Mtaie 2009, Impact of Drainage Systems on Economic Growth, Applied Study on a Developing Countries Group for the Period 1974-2006. Unpublished Master Thesis, King Saud University, Saudi Arabia

4- Ayen,y, 2014, the effect of currency devaluation on output: the case of Ethiopian economy , Journal of economics and international finance, Jimma University, pp 1-8

5- Boyared, D and Gugliemo Maria Caporal 2001, Real exchange rate effects on the balance of trade conintegration and the Marshal - Lerner condition , University of East London,50,51

6- Central Bank of Egypt, March 2014 report, www.cbe.org.eg

7- Christian Payne Buabin 2016, Effect of exchange rate volatility on economic growth in Ghana: An $\mathrm{n}$ empirical investigation, University of Cape Coast. 


\section{The impact of Exchange rate on Macroeconomic fundamentals}

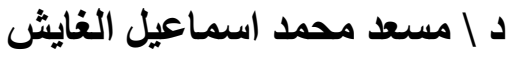

8- International Monetary Fund (IMF)2013, International Reserves and Liquidity in Local Currency, Guidelines for the Preparation of a Standard Data Model, Arabic Edition

9- Kandil, \&others, 2007, the effect of exchange rate fluctuations on economic activity in Turkey, Journal of Asian Economics,pp466-480

10- Krugman (1979), a model of balance of payments crises, journal of money credit and banking, pp.311-320

11- Mohamed Abdel Halim Omar, General Religion Concepts - Indicators Effects, Applied to Egypt, Al-Azhar University

12- Manal Afan, 2009.Evaluation of the Use of Economic Policy Tools in Achieving Economic Balance, A Study on the Egyptian Economy, with Reference to the Experiences of Newly Manufactured Countries, $\mathrm{PhD}$ Thesis, , p. 351 .

13- Ministry of Finance, 2007.http://www.mof.gov.eg

14- Mepherson, M, 2000, Exchange rate and economic growth in Kenya: An Econometrics analysis. African economic policy

15- Mostafa El-Said, 2003,The Egyptian Economy and the Challenges of the Present Situation- Perspectives of Vulnerability-Causes and Treatment

16- National Bank of Egypt,2006 Economic Bulletin, Evolution of Balance of Payments Data, Economic Bulletin No. 4, Volume IX and Fiftieth

17- Ratha, H 2010, Does Deviation work for India? Economic Bulletin 30, pp. 246-260

18-Rutasitara, I 2004 , Exchange rate regimes and inflation in Tanzania , African economic research,pp14,15

19- World Bank, http://www.albankaldawli.org 
The impact of Exchange rate on Macroeconomic fundamentals د \مسعد محمد اسماعيل الغايش

Appendix
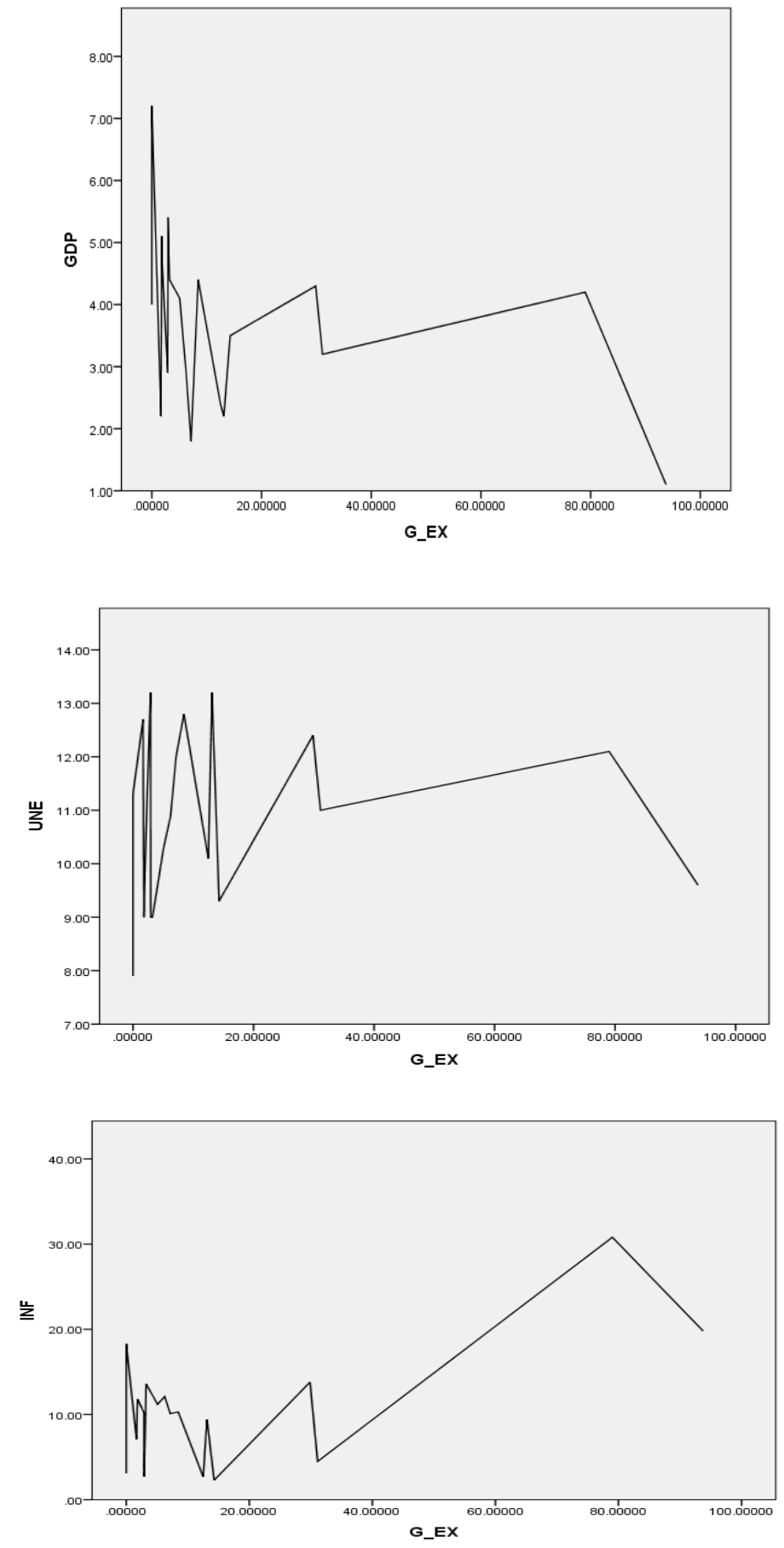
The impact of Exchange rate on Macroeconomic fundamentals

دـ مسعد محمد اسماعيل الغايش
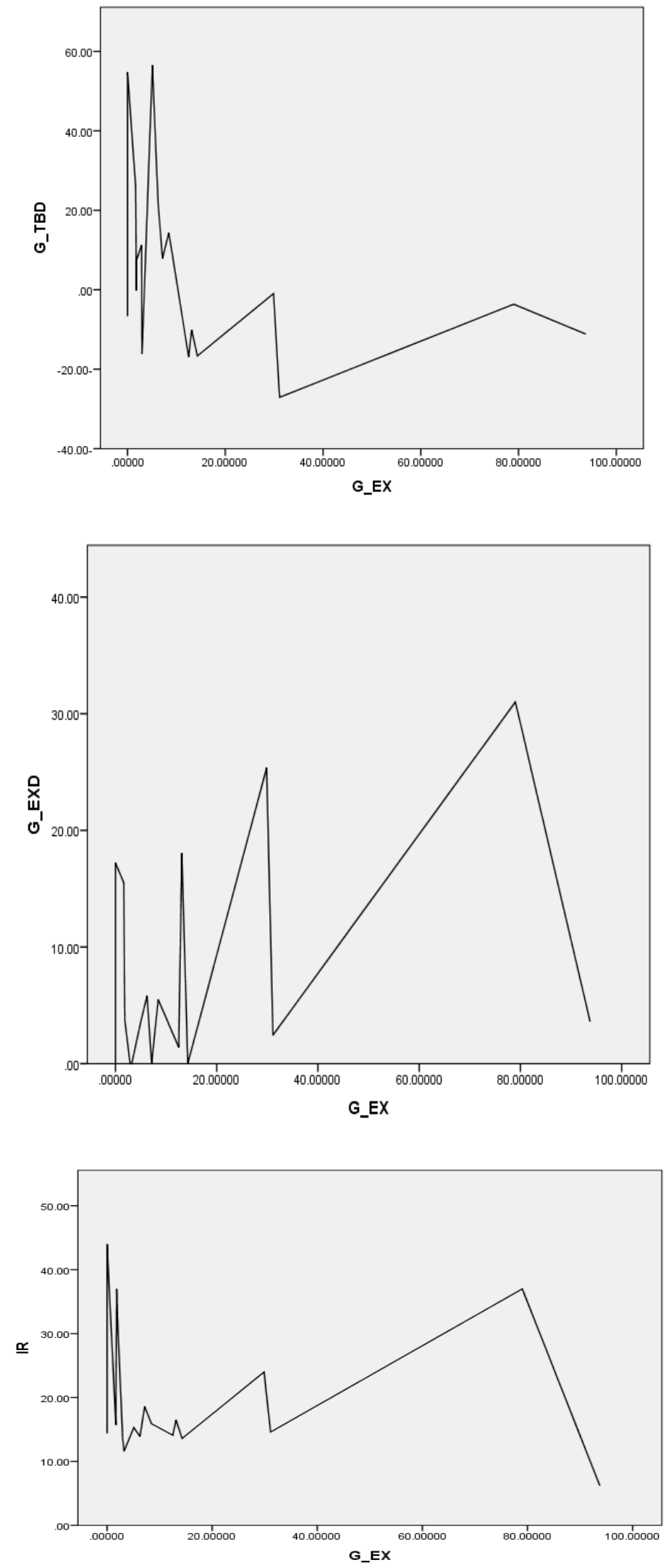